\title{
Exercise as a Therapeutic and Supporting Strategy for Climacteric Symptoms: an Evidence- Based Review
}

\section{Exercício Físico como Estratégia Terapêutica e Coadjuvante nos Sintomas do Climatério: Revisão Baseada em Evidências}

\author{
Rodrigo Gomes Pereira Pinto ${ }^{\mathrm{a}}$; David Michel de Oliveira*b; Anderson Geremias Macedo ${ }^{\mathrm{c}}$; Gisele Soares Passos ${ }^{\mathrm{d}}$
}

\author{
${ }^{a}$ Federal University of Jataí, Physical Education Course. GO, Brazil. \\ ${ }^{b}$ Federal University of Jataí, Health Sciences Academic Unit. GO, Brazil. \\ 'Paulista State University, Stricto Sensu Post-Graduate Program Human Development and Technologies. SP, Brazil. \\ ${ }^{d}$ Federal University of Jataí, Stricto Sensu Post-Graduate Program Health Applied Sciences. GO, Brazil. \\ *E-mail: profdoliveira@ufg.br \\ Recebido em: 03/09/2020 \\ Aprovado em: 08/12/2020
}

\begin{abstract}
Climacteric is a natural process characterized by the female hormones reduction and increased symptoms that interfere in the woman's quality of life. The objective was to raise scientific evidence on the physical exercise effects as a therapeutic strategy on climacteric symptoms. This systematic review study accessed the Virtual Health Library (VHL) and consulted articles from the last 10 years, with the following eligibility criteria; inclusion, scientific articles published in the last 10 years, with clinical, quasi-experimental, cross-sectional design and case studies conducted with women in the climacteric. Articles published before 2010 with delineations were excluded; epidemiological, systematic review, meta-analyzes, experimental studies with animal model. The studies included in the review were read in full, critically analyzed and categorized. The findings showed that active women have a reduction in vasomotor and somatic symptoms of the climacteric, also collaborating in the prevention of diseases prevalent in this period. Aerobic physical exercise improves physical fitness and quality of life indicators of climacteric women. In clinical practice, aerobic exercise can be considered an auxiliary strategy in the climacteric symptoms treatment and female health improvement.
\end{abstract}

Keywords: Climacteric. Health. Physical Exercise.

\section{Resumo}

O climatério é um processo natural caracterizado pela redução dos hormônios femininos e aumento de sintomas que interferem na qualidade de vida da mulher. Objetivou-se levantar evidências científicas sobre os efeitos do exercício físico como estratégia terapêutica na sintomatologia climatérica. Este estudo de revisão sistemática acessou a Biblioteca Virtual de Saúde (BVS) e consultou artigo dos últimos 10 anos, com os seguintes critérios de elegibilidade; inclusão, artigos científicos com delineamento clínico, quase-experimental, transversal e estudos de caso realizados com mulheres no climatério. Foram excluidos artigos publicados anterior a 2010, com delineamentos; epidemiológico, revisão sistemática, metanálises, estudos experimentais com modelo animal. Os estudos incluidos na revisão foram lidos na integra, analisados criticamente e categorizados. Os achados demonstraram que mulheres ativas apresentam redução dos sintomas vasomotores e somáticos do climatério, também colabora na prevenção de doenças prevalentes nesse periodo. O exercício físico aeróbio melhora a aptidão fisica e indicadores de qualidade de vida de mulheres climatéricas. Na prática clínica o exercício aeróbio pode ser considerado uma estratégia auxiliar no tratamento dos sintomas do climatério e melhora da saúde feminina.

Palavras-chave: Climatério. Saúde. Exercício Físico.

\section{Introduction}

With the technology advancement and research evolution in the health-related area, life expectancy has been growing in recent years, epidemiological studies estimate that in 2050, $22 \%$ of the Brazilian population will be elderly ${ }^{1}$.

With the aging process, the organism suffers functional alterations that can result in chronic non-communicable diseases. In particular, in the female sex the transition from reproductive to non-reproductive life is identified as climacteric that can be initiated from the age of 40 , proceeding to the end of the menstrual cycle and the emergence of menopause, such natural phenomena precede the women's natural aging process ${ }^{2}$.

Climacteric is characterized by the reduction of female hormones (estrogen and progesterone), and its symptomatology is characterized by vasomotor effects (heat waves, headache, insomnia), sexual dysfunctions (atrophy of sexual organs, dryness, libido reduction, dyspareunia), onset of lipid profile disorders and bone metabolism, in addition to urinary incontinence and psychological disorders (fear, insecurity, anxiety and depression symptoms) and quality of life reduction ${ }^{3,4}$.

Hormone replacement therapy is one of the strategies used to modulate the decline of female hormones and to attenuate climacteric-related problems, acting mainly in the relief of their symptoms, however, as any drug strategy, although low, has side effects ${ }^{5}$. On the other hand, the adoption of a healthy lifestyle, such as adequate nutritional consumption associated with regular physical activity, may be important non-drug strategies to help reduce climacteric symptoms ${ }^{6}$.

Physical exercise promotes clinical and functional 
benefits at any stage of life, in climacteric it becomes essential for symptom relief, improved physical conditioning, weight maintenance, pelvic floor strengthening and urinary incontinence control, improvement of psychoemotional aspects and sleep. It also reduces the risk of cardiovascular, osteometabolic and several types of cancer prevalent in middle-aged and mature women ${ }^{4,7}$. Although the benefits are widely recognized, there is still no consensus in the literature on the model, volume, intensity and duration of physical exercise, as well as its efficiency and effectiveness in mitigating the climacteric symptomatology.

Climacteric symptoms reduce the quality of life (QOL) of the female population, on the other hand with physical exercise practice, such effects of symptoms can be minimized and health improved.

Therefore, the carrying out of studies that bring together research on this subject could contribute to the knowledge of researchers and professionals in the elaboration of physical exercise programs as supporting treatment for women with climacteric symptoms and maintenance of female health.

In view of the above, the objective of this study was to verify the effects of physical exercise on climacteric symptoms by reviewing the literature

\section{Development}

\subsection{Methodology}

This is a literature systematic review. This study design uses careful methods on a certain subject to obtain a reliable and general view of the proposed subject. It is of great scientific evidence and is indicated to make a decision of clinical practice and to lead to new directions for future studies ${ }^{8}$.

The database used was the Ministry of Health Virtual Health Library (VHL), consulting publications between 2010 and 2019 in Portuguese and English using the following key words: "climatério/climateric"; "exercício/exercise"; atividade física/physical activity". These terms were tested in the Health Sciences descriptors using the Boolean operator "AND". The search was carried out by 2 researchers independently in August 2019.

\subsubsection{Eligibility Criteria}

Inclusion criteria were defined: scientific articles published in full in the last 10 years, with the following outlines: crosssectional descriptive; clinical, quasi-experimental and case studies, performed with women in the climacteric. With the proposal to gather more recent studies, articles published before 2010 were excluded, also articles of review, metaanalyzes, experimental studies with animal model, abstracts, dissertations and theses were excluded.

From the included articles, reading and analysis were performed. The articles were categorized as follows: author(s); year; design; objective; instruments; intervention, results and main outcomes.

\subsection{Results}

Figure 1 shows the flowchart of the articles search strategy. In the initial search, 82 articles were found, 45 were excluded because they only offer the abstract and did not present their methodology in detail, 16 were published outside the defined years and 2 studies were excluded because they were from the literature review. 19 articles were analyzed by titles, 13 of which were excluded. 6 articles remained which were analyzed in full, 1 excluded because it did not contemplate the subjects. Finally, 5 articles were included in the review.

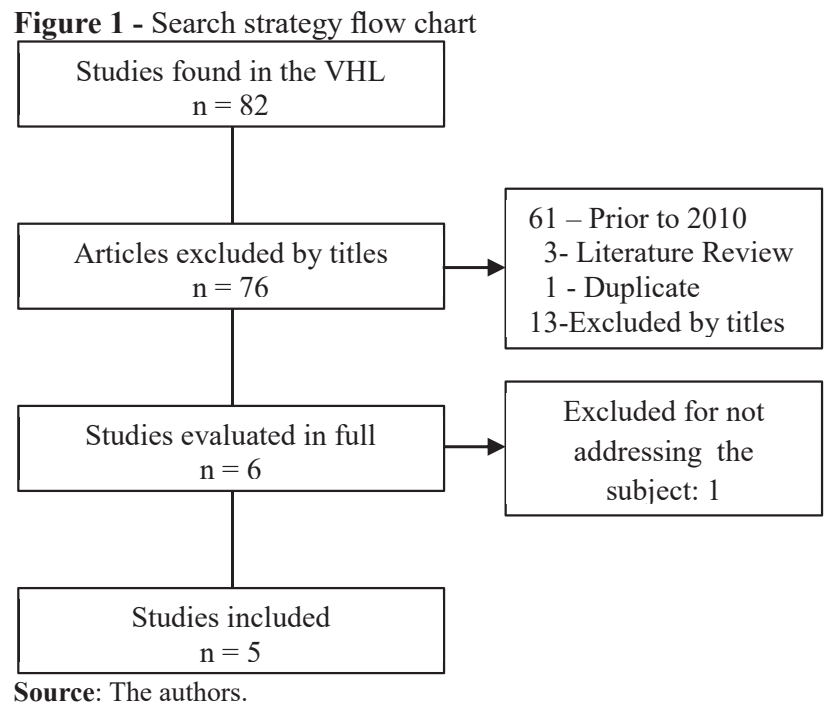

Table 1 describes the studies used in this review with design, objective and instruments.

Table 1 - Analysis of the articles regarding the design, objective and tools used

\begin{tabular}{|c|c|l|l|}
\hline Article & Design & \multicolumn{1}{|c|}{ Objective } & \multicolumn{1}{|c|}{ Tools } \\
\hline $\mathbf{0 9}$ & $\begin{array}{c}\text { Cross- } \\
\text { Sectional }\end{array}$ & $\begin{array}{l}\text { Assess the impact of physical activity practice on QOL of } \\
\text { climacteric women }\end{array}$ & $\begin{array}{l}\text { International Physical Activity Questionnaire } \\
\text { (IPAQ); WHOQOL-Bref; Menopause Rating } \\
\text { Scale (MRS) }\end{array}$ \\
\hline $\mathbf{1 1}$ & Control-Case & $\begin{array}{l}\text { To evaluate the influence of regular aerobic exercise } \\
\text { practice on the QOL and climacteric symptomatology } \\
\text { comparing with a group of sedentary women }\end{array}$ & Menopause Rating Scale-MRS; \\
\hline $\mathbf{1 2}$ & Clinical & $\begin{array}{l}\text { To verify changes in the climacteric symptoms in women } \\
\text { resulting from the practice of an aerobic exercise program }\end{array}$ & $\begin{array}{l}\text { Menopausal index of Blatt and Kupperman } \\
\text { (IMb) }\end{array}$ \\
\hline
\end{tabular}




\begin{tabular}{|c|c|l|l|}
\hline Article & Design & \multicolumn{1}{|c|}{ Objective } & \multicolumn{1}{c|}{ Tools } \\
\hline $\mathbf{1 3}$ & $\begin{array}{c}\text { Quasi- } \\
\text { experimental }\end{array}$ & $\begin{array}{l}\text { To analyze the benefit of aerobic exercise on vasomotor } \\
\text { symptoms of climacteric women }\end{array}$ & $\begin{array}{l}\text { International Physical Activity Questionnaire } \\
\text { (IPAQ); Menopause Rating Scale (MRS) }\end{array}$ \\
\hline $\mathbf{1 4}$ & Clinical & $\begin{array}{l}\text { To evaluate the influence of a therapeutic exercise } \\
\text { program (hydrotherapy) in climacteric and depressive } \\
\text { symptomatology in a group of women }\end{array}$ & $\begin{array}{l}\text { Menopausal index of Blatt and Kupperman } \\
\text { (IMbK) } \\
\text { Geriatric Depression scale of Black and Yesavage }\end{array}$ \\
\hline
\end{tabular}

Source: Research data.

Studies were identified with cross-sectional, case-control and clinical design. These articles exhibited the purpose of evaluating the impact of physical exercise on symptoms, as well as using indirect instruments for analysis.

Table 2 shows the intervention used in the studies and their main results and the conclusion. All the studies were performed with intervention of cardiovascular or aerobic physical exercise, with results of improvement in the climacteric symptoms, among other dimensions investigated.

Table 2 - Intervention, results and the authors' conclusion

\begin{tabular}{|c|c|c|}
\hline Article & Intervention and population & Main outcomes \\
\hline 09 & $\begin{array}{l}370 \text { women } \\
\text { Application of questionnaires }\end{array}$ & $\begin{array}{l}\downarrow \text { Climacteric symptoms in the domains (somatic-vegetative and } \\
\text { urogenital psychological (MRS)) } \\
\uparrow \text { QOL of active women } \\
\text { Conclusion: Physical activity practice can be a determinant of QOL and } \\
\text { reduction of climacteric women symptoms. }\end{array}$ \\
\hline 11 & $\begin{array}{l}132 \text { sedentary (control) } \\
65 \text { practice aerobic exercises: supervised } \\
\text { walks, dance and physical exercise, } 60 \\
\text { minutes } \\
\quad 3 \text { times a week }\end{array}$ & $\begin{array}{l}\downarrow \text { Psychological, vasomotor and urogenital symptom score in women who } \\
\text { practice physical activity regularly: } \\
\text { Conclusion: Regular physical activity contributes to better health } \\
\text { conditions, with a positive impact on climacteric symptoms. }\end{array}$ \\
\hline 12 & $\begin{array}{l}50 \text {-minute walk on a treadmill. } \\
3 \text { times a week for } 8 \text { weeks. }\end{array}$ & $\begin{array}{l}\uparrow \text { aerobic capacity; } \downarrow \text { climacteric symptoms } \\
\text { Conclusion: The results help to reinforce the importance of aerobic } \\
\text { exercise practice for women in climacteric }\end{array}$ \\
\hline 13 & $\begin{array}{l}\text { Aerobic exercise and stretching } \\
30 \text { minutes, } 3 \text { times a week for } 16 \text { weeks. }\end{array}$ & $\begin{array}{l}\downarrow \text { vasomotor symptoms and anxiety, } 55 \% \text { of women improved in one or } \\
\text { more symptoms. } \\
\text { Conclusion: Aerobic exercise had a positive impact on the reduction of } \\
\text { vasomotor symptoms in climacteric women. }\end{array}$ \\
\hline 14 & $\begin{array}{l}\text { Hydro gymnastics: } \\
\text { (warm-up; Walking stretching; } \\
\text { strengthening and relaxation) }\end{array}$ & $\begin{array}{l}\downarrow \text { symptomatology changes from moderate to mild, with a significant } \\
\text { difference }(\mathrm{z}=-3.293 ; \mathrm{p}=0.001) \text {. } \\
\text { Conclusion: The aquatic therapy performed regularly has brought } \\
\text { benefits such as the decrease of symptoms. }\end{array}$ \\
\hline
\end{tabular}
Legend: $\downarrow$ (reduction); $\uparrow$ (improvement, increase). QOL: Quality of life

Source: Research data.

\subsection{Discussion}

Based on the studies analyzed, the results found demonstrate that physical exercise can be considered a great ally to alleviate the symptoms of climate and promote QOL for middle-aged women.

Goncalves et al. ${ }^{9}$ evaluated the impact of physical activity in 370 women with mean age of 49.1 years $( \pm 8.1)$ years with climacteric symptoms, predominantly white ethnic, married, nonsmokers and full high school. Quality of life was evaluated and the level of physical activity was measured. Active women presented better quality of life when compared to sedentary women.

The relationship of physical activity practice and improvement of the quality of life of middle-aged women also involves questions related to endocrine-metabolic, morphological, cardiovascular and psychobiological aspects ${ }^{10}$.

In a case-control study, Tairova and De Lourenzi ${ }^{11}$ investigated the influence of aerobic exercise from mild to moderate intensity in 65 women aged $60.5( \pm 6.9)$ years. Sociodemographic profile, body composition, QOL index, climacteric symptomatology, use of hormonal therapy in the last months and oxygen consumption capacity (VO2 max) were evaluated by tests of maximum treadmill load effort. In the sociodemographic profile, a higher level of schooling and per capita income was observed, and they denied consuming cigarettes in the active group. The body composition of sedentary women was superior to active women and the symptoms of menopause started later. Cardiovascular capacity was significantly higher among active women, QOL scores were high and menopause symptoms were less severe. In short, regular physical activity promoted generalized improvement in health conditions and reflects significantly for healthy aging.

In an experimental study, Avelar, Júnior and Navarro ${ }^{12}$ verified alterations in symptoms in 8 women in climacteric aged 55( \pm 2.7$)$ years, with body mass index (BMI) $\geq 29$ normotensive. They were submitted to an 8 -week program 
with an aerobic exercise with 4 weeks without control and a further 4 weeks with monitoring of the intensity at $70 \%$ of the heart rate. The symptomatology was evaluated in the 2 stages (without control and control) of the physical training. In the initial 4 weeks of training, a decrease in the climacteric symptoms was observed, however, there was a significant reduction in the intensity control phase. Parallel and sequenced results were found in the improvement of aerobic capacity, concluding that exercise when monitored is more efficient for maintaining health in the climacteric

Pérez ${ }^{13}$ analyzed the effects of exposure to unmonitored aerobic physical activities for 4 months in relation to vasomotor symptoms of 100 post-menopausal patients. Although indirect methods were applied for evaluation, it was possible to observe a reduction in vasomotor symptoms, especially in the hot flashes (spontaneous and sudden sensation of heat), an important complaint reported by women in this period and still brought health benefits for the women evaluated.

Agra et al. ${ }^{14}$ investigated the influence of a program of therapeutic exercises in swimming pools with aerobic predominance on menopause symptoms and depression in women aged over 55 years. A decrease in the symptoms of climacteric and depression was observed, and the authors suggest that this type of exercise modality provides social contact and integration, which also leads to regular practice.

Critically, it is emphasized that in the studies found, the authors used indirect instruments such as Menopause Rating Scale (MRS) and Menopausal Index of Blatt and Kupperman (IMBK), are scales used to assess the symptoms intensity in the climacteric period, although they are validated, biological indicators are needed to verify the real effect of physical exercise on the hormonal profile modulation.

\section{Conclusion}

It is concluded that aerobic exercise is considered an effective strategy for reducing climacteric symptoms, improving the quality of life and parallel gains to women's health.

The literature suggests that the physical exercises prescription for women with climacteric symptoms should occur most days of the week, with mild to moderate intensity, and respecting the level of individual physical conditioning to obtain desirable benefits to female health.

\section{References}

1. Kanasi E, Ayilavarapu S, Jones J. The aging population: demographics and the biology of aging. Period 2016;72(1):138. doi: http://dx.doi.org/10.1111/prd.12126.
2. Zanesco A, Zaros PR. Exercício físico e menopausa. Rev Bras Gin Obst 2009;31(5):255-61. doi: http://dx.doi.org/10.1590/ s0100-72032009000500009

3. Silva Filho EA, Costa AM. Avaliação da qualidade de vida de mulheres no climatério atendidas em hospital-escola na cidade do Recife, Brasil. Rev Bras Ginec Obst 2008;30(3):113-20. doi: http://dx.doi.org/10.1590/s0100-72032008005000001

4. Brasil. Ministério da Saúde. Manual de atenção à mulher no climatério/menopausa. 2008. [acesso em 12 maio 2020]. Disponível em http://bvsms.saude.gov.br/bvs/publicacoes/ manual_atenção_mulher_climaterio.pdf>

5. Roberts H, Hickey M. Managing the menopause: An update. Maturitas 2016;86(1):53-8. doi: http://dx.doi. org/10.1016/j.maturitas.2016.01.007.

6. Hoffmann M, Mendes KG, Canuto R. Garcez AS, Theodoro HR, Alice D, et al. Padrões alimentares de mulheres no climatério em atendimento ambulatorial no Sul do Brasil. Ciênc Saúde Coletiva 2015;20(5):1565-74. doi: http:// dx.doi.org/10.1590/1413-81232015205.07942014.

7. Fretta TB. Melhora dos sintomas do climatério por meio da atividade física: uma revisão sistemática. Saúde Rev 2017;17(46):67-78. doi: http://dx.doi.org/10.15600/22381244/sr.v17n46p67-78.

8. Sampaio R.F, Mancini MC. Estudos de revisão sistemática: um guia para síntese criteriosa da evidência científica. Rev Bras Fis 2007;11(1):83-9. doi: http://dx.doi.org/10.1590/ s1413-35552007000100013.

9. Gonçalves AKS, Canário ACG, Cabral PUL, Silva RAH, Spyrides, MHC, Geraldo PC, et al. Impacto da atividade física na qualidade de vida de mulheres de meia idade: estudo de base populacional. Rev Bras Ginecol Obst 2011;33(12):408-13. doi: http://dx.doi.org/10.1590/s010072032011001200006 .

10. Mendoza N, Teresa CD, Cano A, Godoy D, Hita-Contreras F, Lapotka, M, et al. Benefits of physical exercise in postmenopausal women. Maturitas 2016;93(1)83-8. doi: http://dx.doi.org/10.1016/j.maturitas.2016.04.017

11. Tairova O, Sergueevna L, Dino RSD. Influência do exercício físico na qualidade de vida de mulheres na pós-menopausa: um estudo caso-controle. Rev Bras Geriatr Gerontol 2011;14(1):135-45. doi: http://dx.doi.org/10.1590/s180998232011000100014 .

12. Avelar LS, Oliveira Júnior MNS, Navarro F. Influência do exercício físico na sintomatologia de mulheres climatéricas. Rev Bras Gerontol Gereriatr 2012;15(3):537-45. doi: http://dx.doi.org/10.1590/s1809-98232012000300014.

13. Pérez NP. Benefício del ejercicio aeróbico sobre los síntomas vasomotores de pacientes postmenopáusicas. Horiz Med 2013;13(3):15-24.

14. Agra K, Borges A, Araújo K, Carvalho S, Barreto JM, Oliveira, EA. A terapia aquática como coadjuvante na variação do humor em mulheres pós-menopáusicas. Rev Bras Ciênc Saúde 2013;17(4):327-334. doi: http://dx.doi. org/10.4034/rbcs.2013.17.04.02 